${ }^{1}$ Beaumont W. Experiments and observations on the gastric juice, and the physiology of digestion. Plattsburgh: F P Allen, 1833.

${ }^{2}$ Rhodes J. Etiology of gastric ulcer. Gastroenterology 1972;63:171-82.

${ }^{3}$ Clémençon GH, ed. Duodenogastric reflux symposium. Scand $\mathcal{f}$ Gastroenterol 1981;16,suppl 67:1-257.

${ }^{4}$ Keane FB, Dimagno EP, Malagelada J-R. Duodenogastric reflux in humans: its relationship to fasting antroduodenal motility and gastric, pancreatic, and biliary secretion. Gastroenterology $1981 ; 81: 726-31$.

${ }^{5}$ Muller-Lissner SA, Sonnenberg A, Blum AL. Gastric emptying and postprandial duodenogastric reflux in type 1 gastric ulcer. In: Weinbeck $\mathrm{M}$, ed. Proceedings of 8 th international symposium on gastrointestinal motility. New York: Raven Press. (In press.)

${ }^{6}$ Ehrlcin H-J. Gastric and duodenal motility in relation to duodenogastric reflux in healthy dogs. Scand 7 Gastroenterol 1981;16, suppl 67:23-9.

${ }^{7}$ Rhodes J, Barnardo DE, Phillips SF, Rovelstad RA, Hoffman AF. Increased reflux of bile ints the stomach in patients with gastric ulcer. Gastroenterolngy $1959 ; 57: 241-52$.

${ }^{8}$ Black RB, Roberts G, Rhodes J. The effect of healing on bile reflux in gastric cancer. Gut $1971 ; 12: 552-8$.

${ }^{9}$ Griffith GH, Owen GM, Campbell H, Shields R. Gastric emptying in health and in gastroduodenal disease. Gastroenterology 1968;54:1-7.

${ }^{10}$ Schcurer UC, Schlegel JF, Kelly DG, Code ChF. Chronic bile exposure increases resistance of canine gastric mucosa to bile. Scand $\mathcal{7}$ Gastroenterol 1981;16,suppl 67:205-10.

11 Johnson AG, McDermott SJ. Lysolecithin : a factor in the pathogenesis of gastric ulceration? Gut $1974 ; 15: 710-3$.

12 Hoare AM, Jones EL, Alexander-Williams J, Hawkins CF. Symptomatic significance of gastric mucosal changes after surgery for peptic ulcer. Gut $1977 ; 18: 295-300$.

${ }^{13}$ Mosimann R, Loup P, Fontolliet C, Mosimann F. Post-operative reflux gastritis: results of surgical treatment. Scand $\mathcal{F}$ Gastroenterol $1981 ; \mathbf{1 6}$, suppl $67: 237-9$.

\section{Families in high-rise flats}

Poor housing is known to be bad for health, so it is doubly disappointing that the high-rise flats built in the 1960s have been associated, despite their modern amenities, with an increased prevalence of mental illness. It was, after all, the urgent need for slum clearance and rebuilding of the innercity areas in the postwar years that encouraged local authorities to opt for this form of high-density housing. Since then the architects have learnt that with careful planning very high densities of population may be housed without resort to highrise buildings, ${ }^{1}$ but that provides no comfort for those who must continue to occupy the tower blocks of the ' $60 \mathrm{~s}$.

Probably the most quoted conclusion to come out of studies on the residents of high-rise flats is that mothers of young children are particularly at risk of psychiatric illness. Fanning ${ }^{2}$ studied servicemen's families in Germany and found that young wives (aged 20-29) in flats of up to four storeys consulted their general practitioners about psychoneurotic symptoms more frequently than a comparable group of wives living in houses. In 1970 the National Society for the Prevention of Cruelty to Children ${ }^{3}$ conducted interviews with one or more members of 280 families in high-rise flats. The findings confirmed and extended Fanning's conclusions by showing that mothers with young children living in tower blocks were particularly liable to social isolation and symptoms of psychiatric disorders. In contrast, in families with teenage children the mothers were reported to be relatively symptom free.

More recently, however, Brown et al $^{4}$ have shown that mothers with three children aged 14 or less are at higher risk of depression than women generally, raising doubts about whether the studies on flats were adequately controlled for factors apart from housing. These authors included poor housing as a factor in chronic psychiatric morbidity (the four indices being overcrowding, extreme physical deprivation, problems with noise, and lack of security of tenure), but they made no specific mention of high-rise accommodation.

Two well-designed studies have answered some of these questions. Richman ${ }^{5}$ looked at three matched groups of 25 London families, each with at least two children aged under 5 , living in high-rise flats, low-rise flats, and houses. Each of the three groups rented accommodation from the local authority. Though she found no difference in mental health in the three groups, the women living in high-rise flats expressed greater dissatisfaction with their housing. This was also reflected in the expressed intention to move in $48{ }_{\circ}^{\circ}$ of the people living in high-rise flats, $28 \%$ of the people in low-rise flats, and $12 \%$ of the people living in houses.

A study in Bristol by Ineichen and Hooper ${ }^{6}$ tends to support Richman's findings. In a redeveloped central urban area about a quarter of the wives in high-rise flats were receiving medical treatment for psychiatric symptoms. In house dwellers living in the same area, however, the proportion receiving treatment was also high. In a follow-up study ${ }^{7} 18$ months later $40 \%$ of the house dwellers and $60 \%$ of the flat dwellers had moved away. The mental health of the remaining families in the different groups had become nearly comparable.

Exactly how important living in high-rise flats is as a factor in the development of mental illness remains uncertain, but from a consumer's point of view certain facts have been established. The strong dissatisfaction with this sort of accommodation in families with young children, though it may be partially offset by unusually good play facilities, should determine that such families should be housed elsewhere whenever possible.

Living in a high-rise flat may be ideal for some people, but it seems hazardous and stressful for certain vulnerable disadvantaged groups. When the lift fails, the rubbish chute is blocked, and there is inadequate space for children's play, then the elderly, the physically handicapped, and mothers with young children are placed at risk. Noisy, inconsiderate tenants place an intolerable burden on all others.

In planning future research close attention should be paid to selecting adequate control groups, particularly in the light of the sociological insights of Brown and Harris. ${ }^{8}$ We need to understand more about the reasons for the rapid turnover of tenants in local authority housing and to learn how to identify those families able to adjust in some degree and even derive satisfaction from their accommodation as well as those likely to suffer adversely.

D A G Cook Consultant senior lecturer in mental health H GeThin MORGan Professor of mental health

University of Bristol,

Bristol BS2 8DZ

1 Roberts TRW. Low rise, high density. Town and Country Planning 1971 39.127-30.

2 Fanning DM. Families in flats. Br Med f 1967;iv:382-6.

${ }^{3}$ Stewart WFR. Children in flats. A family study. London: National Society for the Prevention of Cruelty to Children, 1970.

- Brown GW, Bhrolchain MN, Harris T. Social class and psychiatric disturbance among women in an urban population. Sociology 1975;9: 225-54.

${ }^{5}$ Richman N. The effects of housing on pre-school children and their mothers. Dev Med Child Neurol 1974;16:53-8.

6 Ineichen B, Hooper D. Wives' mental health and children's behaviou problems in contrasting residential areas. Social Science and Medicine $1974 ; 8: 369-74$.

${ }^{7}$ Hooper D, Ineichen B. Adjustment to moving; a follow-up study of the mental health of young families in new housing. Social Science and Medicine 1979;13D:163-8.

${ }^{8}$ Brown GW, Harris T. Social origins of depression. A study of psychiatric disorder in women. London: Tavistock Publications, 1978. 